\title{
SOME CONCLUSIONS OF THE LUCKNOW CONFERENCE
}

Probably the most important subject which came before the recent Conference at Iucknow was: How to check the Moslem advance among pagan and nominal Christians, imperfectly instructed and without an experimental knowledge of living Christianity. The first peril presents itself in Africa, and both are found in Russia.

The Cairo Conference in 1906 called attention to the recent spread of Islam in Africa, largely due to conditions resulting from the establishment of European protectorates, with the initiation of more stable and civilised modes of government over great regions where paganism is deprived of its natural weapons of defence by force against the onset of a new faith. This appears to be an inevitable result of political change, but in addition many officials, through mistaken ideas as to the most prudent policy, actively aid Islam by discriminations in favour of Moslems as against Christians or pagans. The situation in Russia has never been fully explained in English till Mme. Bobrovnikoff contributed the able and luminous paper for the Lucknow Conference which appeared in the first number of this magazine. It would not be strange if we should soon find ourselves confronted with the same spirit of aggression elsewhere. The Mohammedans of India are now roused by the advance of Christianity among the out-castes, and are striving to win them over to their own faith.

To those who regard Islam as an improvement on heathenism and even as a stepping-stone to Christianity, this may not be a subject of regret, but others who have studied the progress of this intolerant religion from its inception to the present day, through thirteen centuries in which it has desolated some of the fairest portions of the earth, may well be alarmed at the prospect of renaissance for a faith whose history from the beginning 
has been written in blood, tears and fire. The apologist for Islam has never yet been able to justify the system by the obvious test of its fruits : its practical and invariable working out of the original character stamped on it by its founder. We search in vain for instances of a Moslem who is happy as a true Christian is happy, or good as such a one is good. Leaving the particular for the general, history gives us no instance where the acceptance of Islam has aided a race to pass onward to the higher faith. Such being the case, Christians at least must view with grave apprehension what is coming to be known as the Moslem advance and must speedily take measures to meet it.

The thought arises at once of fighting fire with fire, as when a prairie is in a blaze the settler hastily burns off the ground surrounding his home and thus anticipates the flames by leaving them nothing on which to feed. A decided advance on the part of Christians must be called for. The first requisite is faith which truly believes that "the things which are impossible with man are possible with Cod." $\mathrm{He}$ is able to raise up Christian missionaries in Russia, closed as it is to evangelising efforts from without. He is able to put into the hearts of sinners such a conviction of their sin and misery that none but Christ can satisfy it. He is able to "carry the battle to the enemy's gate," giving us many converts from Islam itself, "who shall come up to the help of the Lord against the mighty." "By whom shall Jacob rise?" What are our resources? Whom has God prepared to do this thing ?

Every thoughtful mind must have been struck by the remarkable providence which has preserved the old Christian Churches of the East from absorption into the dominant Moslem powers and annihilation. They have been like the bush in the desert " which burned and was not consumed." No less remarkable is the fact that in the last century, when they had sunk into formalism and decay, God sent them the light again by messengers from the West, so that in each dead and superstitious Church, though like "salt that has lost its savour," life is again stirring and the Spirit of God has separated 
from and in them, companies whose life testifies to the power of a pure Gospel. At the same time in every land Churches are won from pure paganism. Is it not on these we must rely to check the advance of Islam ? The great majority of these Christians, we must frankly confess, have not yet seen the opportunity before them. They do not believe the conversion of Moslems possible, nor have they learned deeply to desire it. They fear also for their own safety should they venture to preach Christ to Islam. Perhaps for this reason God has permitted the awful massacres of the last sixteen years in Turkey to draw the world's attention to the true nature of this religion, that it may be judged by its works; also to impress on Christians the futility of hoping to disarm hostility by neglect.

It is well known that religious fanaticism was only one element in those massacres. The greed of Moslems was aroused by seeing their Christian neighbours prospering more than they in material things, so they seized the opportunity to destroy them. If a Christian is to suffer death, would he not rather perish for preaching the Gospel of Jesus Christ than for having wealth which arouses the cupidity of his neighbours?

God alone is able to waken the Churches brought into contact with the power of Islam to see their glorious opportunity and to rise to the occasion. Is it not possible for us to understand something of the divine strategy and to fall in with it, with holy boldness at His call and following His leadership? Are we no longer to lie on our faces but to speak to the children of Israel that they go forward? It would seem from the following resolutions, unanimously adopted by the Conference, that this policy is the one which commends itself to the men and women present at Lucknow :-

\section{"IV. Urgency of the Mohammedan Problem.}

"That this Conference, in view of the steady advance of Islam, not only among various Animistic tribes and other peoples, but also to some extent among historic Christian Churches and recently Christianised pagans, expresses the conviction that it is absolutely necessary 
that Christendom at large, and more especially the missionary boards and committees of the Churches, which we represent, should forthwith take practical measures for a more comprehensive and systematic prosecution of the work among Moslems.

"VII. The Needs of Animistic Tribes and Depressed Classes.

"That this Conference is persuaded that, in order to stem the tide of Moslem advance, it is important to strengthen the work among Animistic communities and depressed classes affected by this advance; for we are clearly of opinion that adoption of the faith of Islam by the pagan people is in no sense whatever a steppingstone towards, or a preparation for, Christianity, but exactly the reverse.

"XII. Appeal to the Churches at Work in India.

"That this Conference, recognising the urgency of the call to the Christian Church at the present time to make largely increased efforts to stem the advance of Islam in Africa, and remembering the share taken by emigrants and labourers from India in the recent development of parts of that continent, desires to commend to the careful attention of missions working throughout India the consideration of the possibility of sending some Christian workers from their land to the help of the Church in Africa.

"It would more particularly commend this matter to the consideration of the National Missionary Society and other similar indigenous bodies in India, feeling sure that, if they could make some contribution to this great work, they would deepen the spirit of missionary zeal in their members and bring God's richest blessing upon it."

If such a policy is adopted, it will be quite in order to extend the scope of the last resolution, so that the spirit of it may include not only India, but indigenous Churches all over what is now known technically as "the mission field."

G. Y. Holliday。

Tabriz, Persia. 